\title{
ON THE DRASTIC EFFECTS OF INHOMOGENEITY IN SHPOLSKY SYSTEM SPECTRA
}

1. The aim of this paper, based mainly on $\left[{ }^{1,2}\right]$, is to point to the effects of inhomogeneity in proper Shpolsky systems. The inhomogeneous broadening may obscure, for instance, the weak components of secondary radiation, such as hot luminescence $\left[{ }^{3,4}\right]$ and Raman scattering *. Besides, the presence of phonon bands in the spectra of these systems $\left[{ }^{6,7}\right]$ may lead to analogical difficulties.

The predominantly inhomogeneous nature of the spectra broadening of aromatic compounds in different solid matrices, exhibiting broad band spectra under "white" excitation, has been studied in $\left[{ }^{8,9}{ }^{9}\right.$. The role of inhomogeneity in the impurity spectra was also clearly demonstrated in $\left[{ }^{10,11}\right]$.

In this paper we consider the Shpolsky systems, most convenient for displaying quasiline spectra, where nevertheless a drastic inhomogeneous broadening is present.

2. Studying the nature of multiplets in the vibronic spectra of perylene in $n$-hexane and in other solvents' matrices under monochromatic (of the order of no-phonon line widths) and sufficiently intensive excitation, nonresonant with the absorption lines, a number of emission lines besides ordinary and hot $\left[{ }^{3,4}\right]$ luminescence were observed. This emission reveals a number of qualities characteristic of the resonant Raman scattering on local vibrations of a perylene molecule $\left[{ }^{5}\right]$. Actually, as shows the following analysis, a peculiar statistical line broadening is responsible for such an emission.

The ordinary luminescence spectrum of perylene in $n$-hexane at $4.2 \mathrm{~K}$ is well known $\left[{ }^{12}\right]$. The number of multiplet components in this spectrum is $\geqslant 8\left[{ }^{4}\right]$. It has been shown that different components can be assigned to different unequivalent impurity centres [ $\left.{ }^{4}\right]$ (multiplicity in Shpolsky's sense $\left.\left[{ }^{13}\right]\right)$.

3. The emission of the species was excited by a xenon arc DXSh-1000 through a light-grasp $(1: 3)$ double monochromator MDR-1. The width of the excitation band could be narrowed down to $2-3 \mathrm{~cm}^{-1}$. At the exit slit of the analyzer (a double monochromator DFS-12) emission was detected by means of a photomultiplier FEU-79 as single photon detector. The sealed concentrated solutions in flat glass tubes were cooled down to $4.2 \mathrm{~K}$ by a straight immersion into liquid helium.

* Our paper $\left.{ }^{5}\right]$ that concerns Raman scattering in Shpolsky systems, as it will appear from present paper, is a didactic example of improvidence; besides, in hot luminescence spectra the effects of inhomogeneity looking like resonant Raman scattering, are observed [ $\left.{ }^{1}\right]$. 

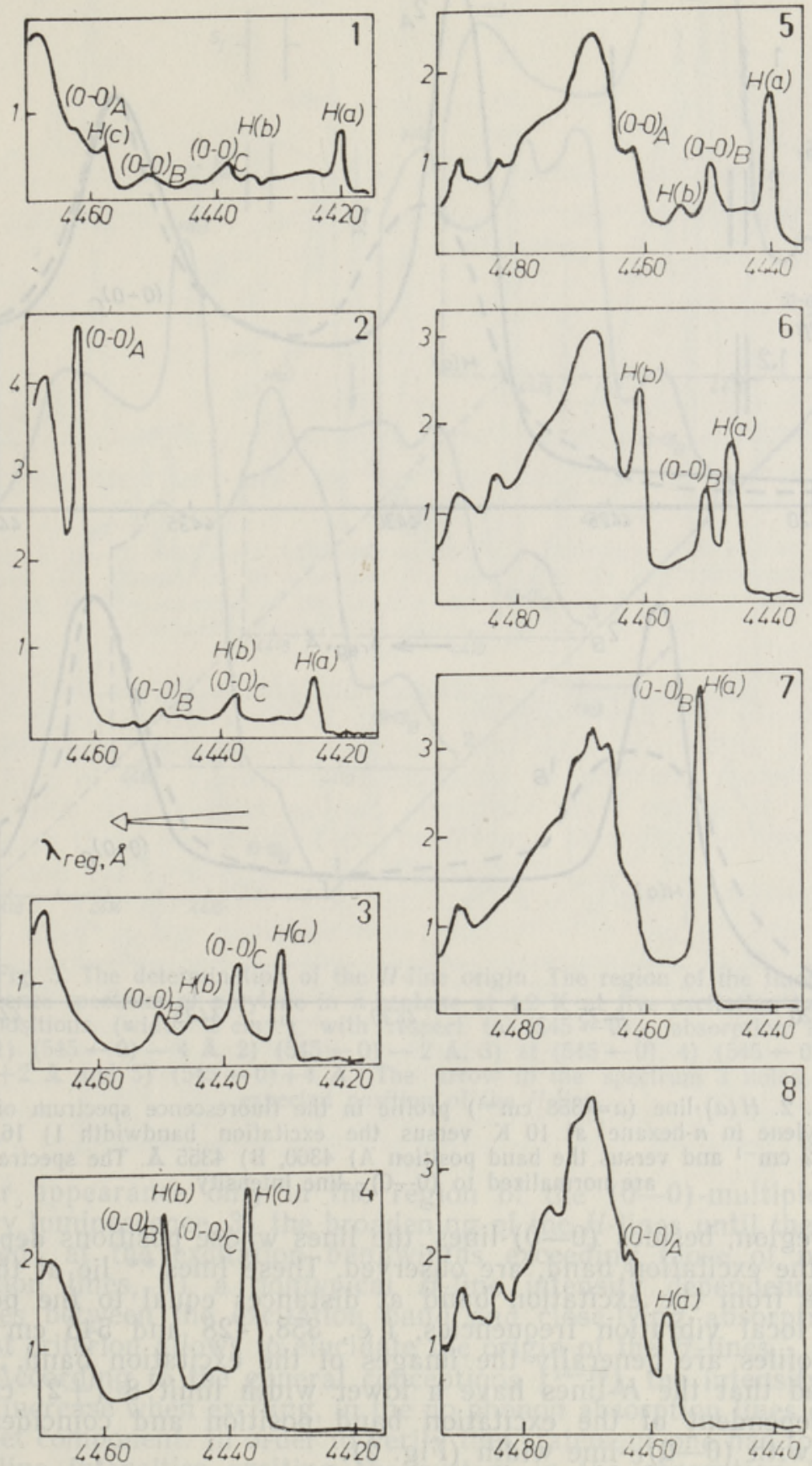

Fig. 1. $(0-0)$-multiplet region of the fluorescence spectrum of perylene in $n$-hexane at $4.2 \mathrm{~K}\left(a=358, b=428\right.$ and $\left.c=545 \mathrm{~cm}^{-1}\right)$. The position of the excitation band (width $6 \mathrm{~cm}^{-1}$ ) has been fixed at 1) 4351,2$) 4356,3) 4361,4$ ) 4366, 5) 4371,6$) 4376,7) 4381$ and 8) $4386 \AA$. Detection bandwidth $5 \mathrm{~cm}^{-1}$.

4. Fig. 1 demonstrates a series of eight luminescence spectra obtained at eight different excitation band positions. One can see that in the same 

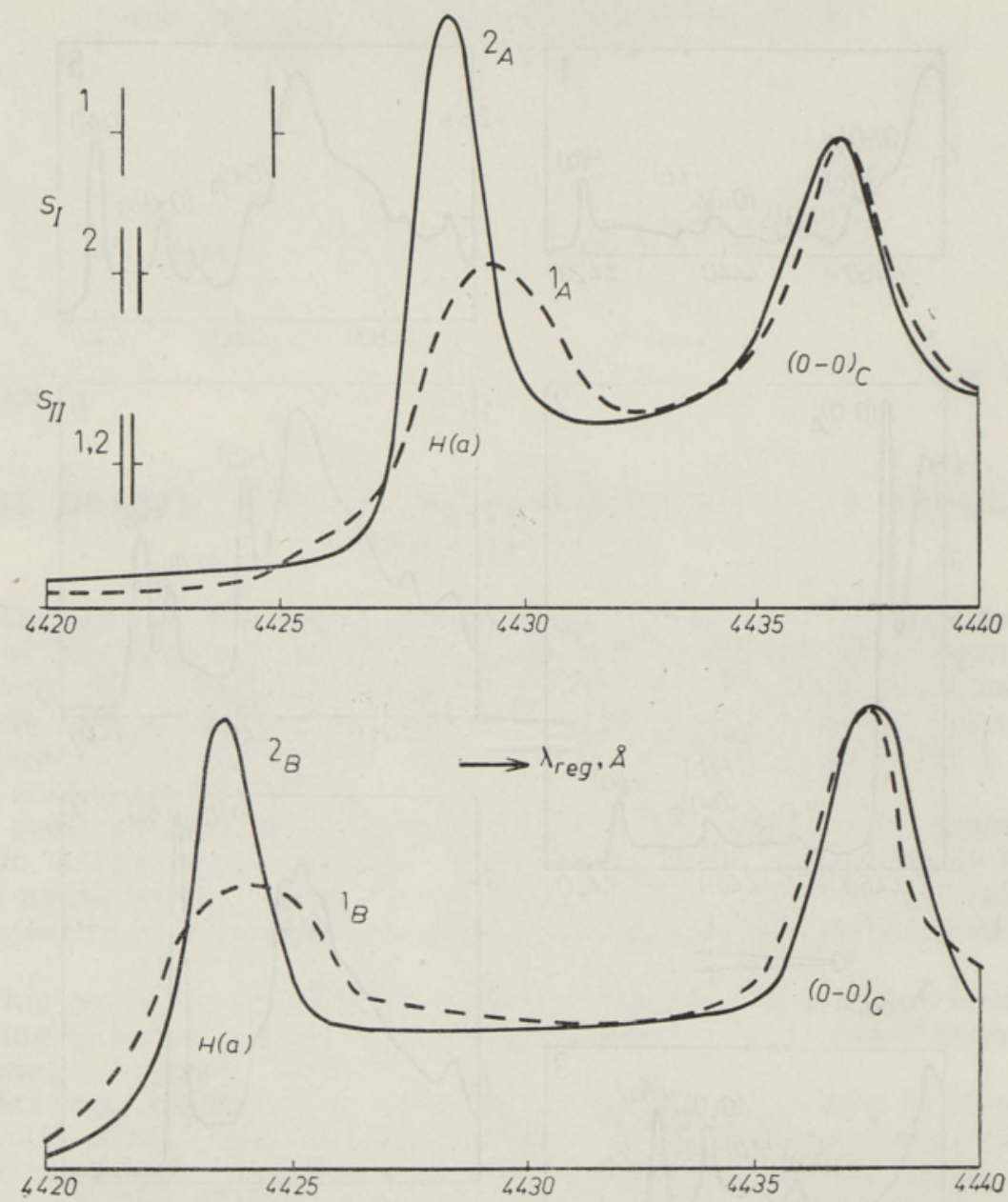

Fig. 2. $H(a)$-line $\left(a=358 \mathrm{~cm}^{-1}\right)$ profile in the fluorescence spectrum of perylene in $n$-hexane at $10 \mathrm{~K}$ versus the excitation bandwidth 1) 16 , 2) $2 \mathrm{~cm}^{-1}$ and versus the band position A) 4360 , B) $4355 \AA$. The spectra are normalized to $(0-0) c$-line intensity.

spectral region, besides $(0-0)$-lines, the lines whose positions depend on those of the excitation band, are observed. These lines** lie at the long wave side from the excitation band at distances equal to the perylene molecule local vibration frequencies, i. e., 358,428 and $545 \mathrm{~cm}^{-1}$. The $\mathrm{H}$-line profiles are generally the images of the excitation band. It was ascertained that the $H$-lines have a lower width limit $8( \pm 2) \mathrm{cm}^{-1}$ at $10 \mathrm{~K}$, independent of the excitation band position and coincident, for instance, with $(0-0)_{c}$-line width (Fig. 2).

As mentioned, the $H$-lines behave as resonant Raman scattering (RRS) lines. Indeed, 1) the constancy of the distance (in energy scale) to the excitation band, 2) revelation of the perylene molecule local vibrations, 3 ) the residue linewidths at essential narrowing of the excitation band, all these are facts typical of RRS. But there also exists a number of arguments inconsistent with RRS: 1) abnormally high $H$-line intensities,

\footnotetext{
** For convenience, further we shall mark the lines under discussion as $H$-lines.
} 


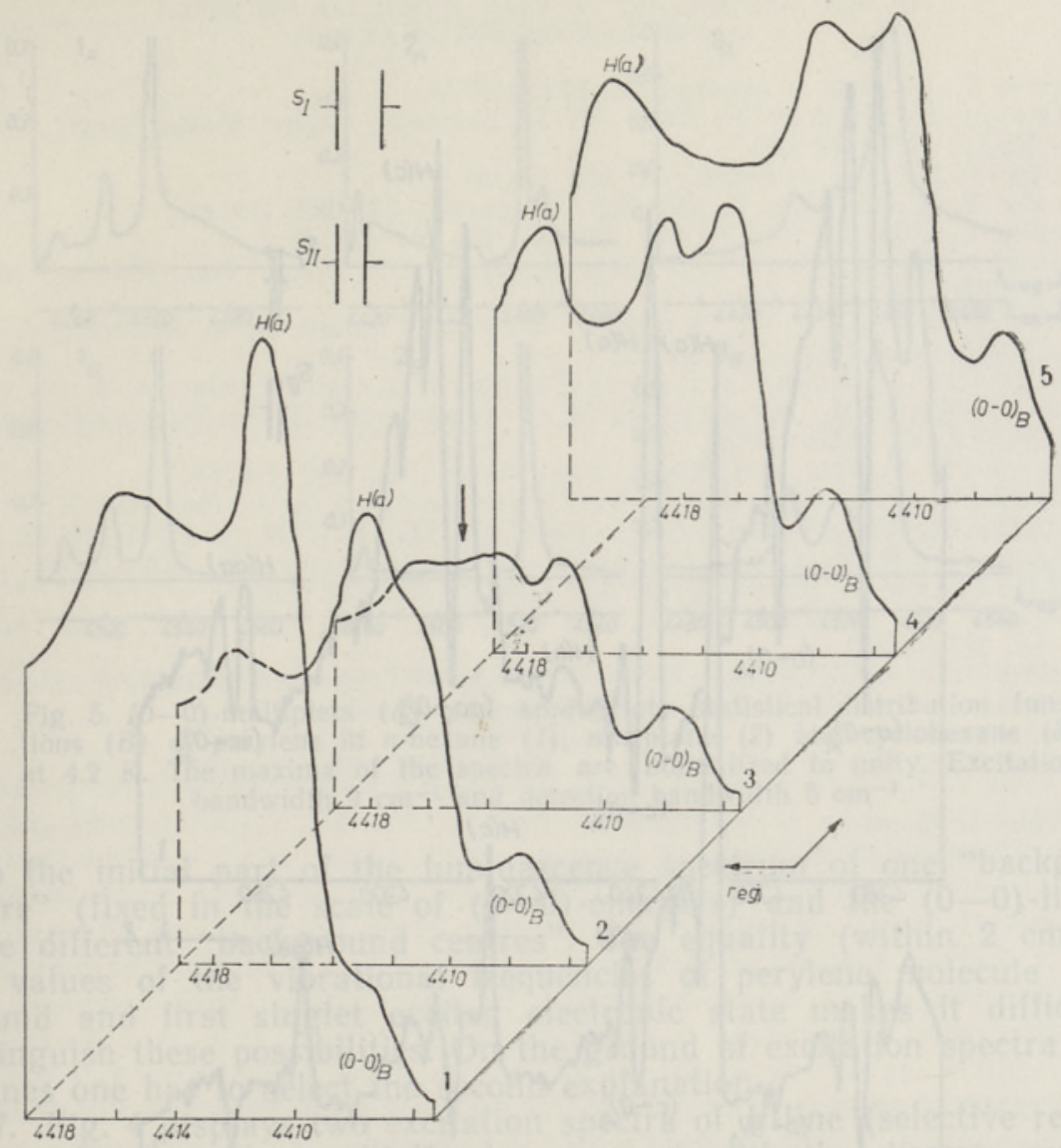

Fig. 3. The determination of the $H$-line origin. The region of the fluorescence spectrum of perylene in $n$-heptane at $4.2 \mathrm{~K}$ at five excitation band positions (width $8 \mathrm{~cm}^{-1}$ ) with respect to $(545 \leftarrow 0)_{A}$ absorption line 1) $(545 \leftarrow 0)-4 \AA, 2)(545 \leftarrow 0)-2 \AA, 3)$ at $(545 \leftarrow 0), 4)(545 \leftarrow 0)+$ $+2 \AA$ and 5$)(545 \leftarrow 0)+4 \AA$. The arrow in the spectrum 3 notes the expected position of the $H$-line.

2) their appearance only in the region of the $(0-0)$-multiplet of the ordinary luminescence, 3 ) the broadening of the $H$-lines until they become "smeared" at the excitation bandwidths exceeding those of no-phonon absorption lines, 4) a nontypical $H$-line intensity dependence on the distances between the excitation band and close-lying absorption lines. The last criterion allows to elucidate the origin of the $H$-lines.

5. According to the general conceptions $\left[{ }^{14-16}\right]$, the intensity of RRS should increase when exciting, in the no-phonon absorption lines of certain multiplet component. In order to verify this statement one has to compare the $H$-line intensities exciting the system in the absorption lines and nearby. This is the general idea of the experiment intended for distinguishing the two above-mentioned interpretations of the $H$-lines. The most convenient system for such an experiment turns out to be perylene in $n$-heptane. In the case of other $n$-alcanes the multiplet components lie "inadvisably", which leads to an ambiguity in the interpretation. Fig. 3 shows the results of the experiment. One can see that if the excitation approaches resonance, the $H$-line intensity decreases. This is observed 


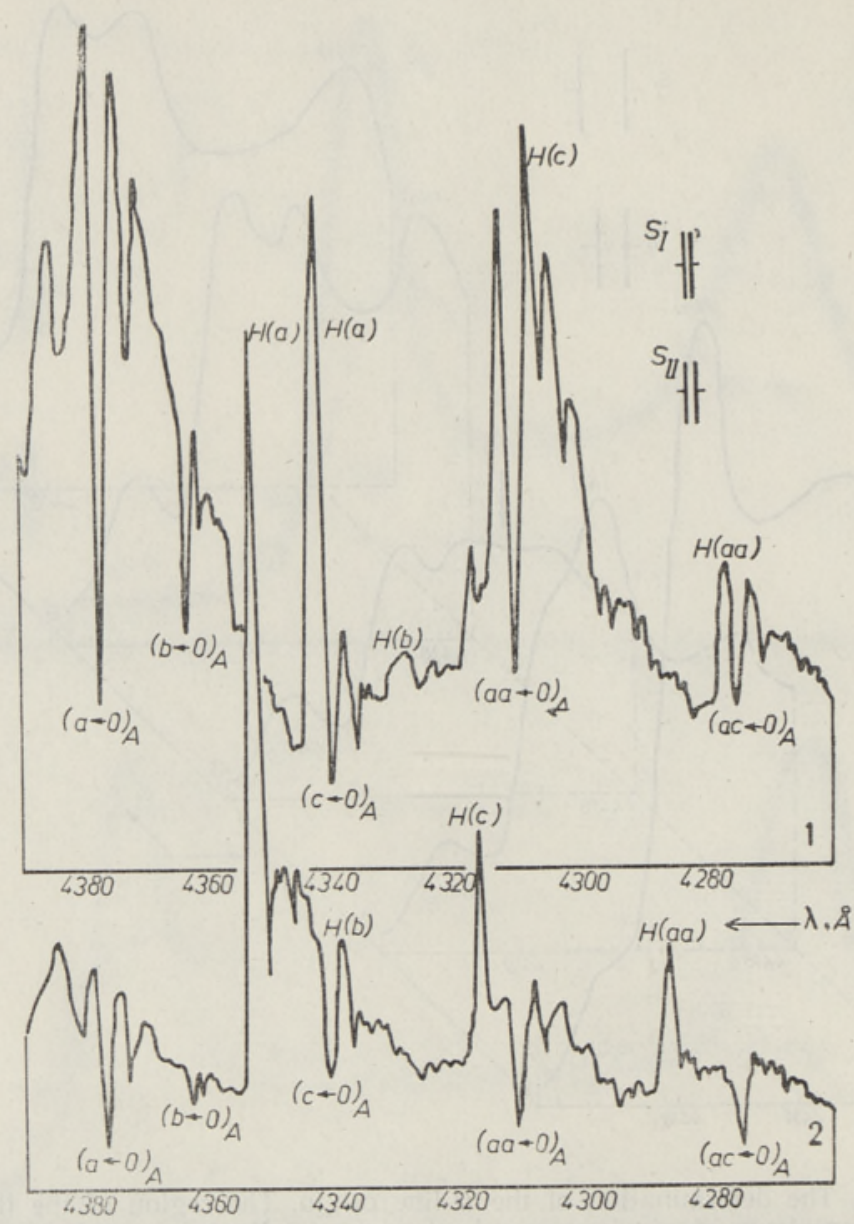

Fig. 4. The region of excitation spectrum of $H$-lines at 1) 4410 and 2) $4420 \AA$ of perylene in $n$-octane at $4.2 \mathrm{~K}$. Subscript $A$ denotes the main multiplet component. Absorption lines are assigned using abbreviations $a=353, b=424$, $c=543 \mathrm{~cm}^{-1}$. The mark $H(x)$ here notes an absorption line of $H$-line.

reliably enough on the background of the phonon band of one $(0-0)$-line. At resonant excitation (spectrum 3) the $H$-line vanishes. Thus the $H$-lines are not of the RRS origin and should be explained as ordinary luminescence lines of the so-called "background centres".

6. The "background centres" can be treated as impurity molecules trapped into $n$-alcane matrice in a dispersed way, which for some reason have the $(0-0)$-transition energies different from the ones for the discrete multiplet components. This means that, in addition to the Gaussian statistical distribution of the (0-0)-energies within the discrete multiplet components, there exists also a continuous one. The dispersed character of the luminescence centres responsible for the $H$-lines seems to become obvious from the measurements of the lower width limit (Fig. 2). In the case of a complicated aggregate nature of such luminescence centres the uniform residual linewidth should be higher.

One has to specify the relation between the $H$-lines and the "background centres". The problem is that the three $H$-lines (Fig. 1) can be 

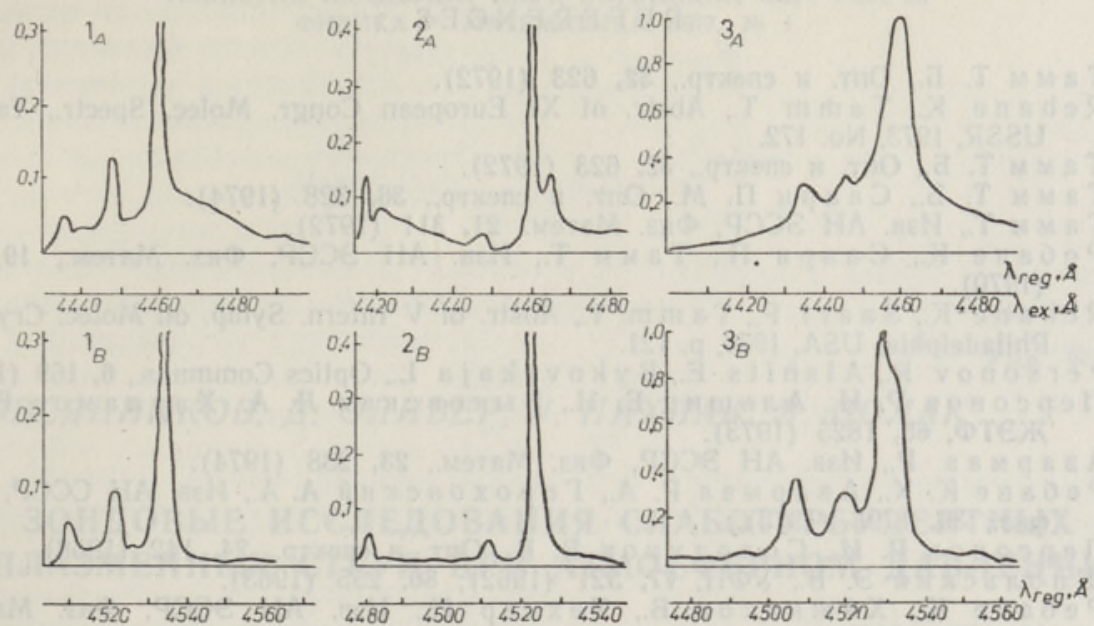

Fig. 5. $(0-0)$-multiplets $(A)$ and appropriate statistical distribution functions $(B)$ of perylene in $n$-hexane $(1), n$-heptane (2) and cyclohexane (3) at $4.2 \mathrm{~K}$. The maxima of the spectra are normalized to unity. Excitation bandwidth $9 \mathrm{~cm}^{-1}$ and detection bandwidth $5 \mathrm{~cm}^{-1}$.

both the initial part of the luminescence spectrum of one "background centre" (fixed in the scale of $(0-0)$-energies) and the $(0-0)$-lines of three different "background centres". The equality (within $2 \mathrm{~cm}^{-1}$ ) of the values of the vibrational frequencies of perylene molecule in the ground and first singlet excited electronic state makes it difficult to distinguish these possibilities. On the ground of excitation spectra of the $H$-lines one has to select the second explanation.

7. Fig. 4 displays two excitation spectra of $H$-line (selective registration is fixed at the positions non-resonant with the discrete multiplet components). One can see the maxima corresponding to the absorption lines of the "background centres" and the holes at the positions of the absorption lines of the discrete multiplet components. The observed energy redistribution has led us to the conclusion that the "background centres" are complementary to the centres responsible for the discrete components.

Summing up, one has to consider the statistical distribution of the impurity molecules on their $(0-0)$-energies in the Shpolsky system as a curve with a few or more sharp maxima representing multiplet components and differing from zero in all region of a $(0-0)$-multiplet.

To measure the real distributions of the impurity molecules in solid matrices, we have recently elaborated an experimental, so-called "double scanning" technique $\left[{ }^{17}\right]$. Fig. 5 presents certain distributions of perylene molecules.

8. Obviously we have observed the same phenomenon as Personov has $\left[{ }^{8,9}\right]$, when exciting broad impurity spectra with laser into the $(0-0)$-band. The main distinguishing feature in the present case of impurity molecules in "appropriate" matrices can be expressed by the fact that along with "background" luminescence a considerable amount of the emission from the discrete multiplet components, excited via their phonon bands, remains. The different exciting sources (narrow band filtered from xenon arc spectrum and lines from the lasers) evidently do not affect the essential side of the phenomenon [ $\left.{ }^{11}\right]$.

Finally I have the great pleasure to thank Professor K. Rebane for valuable discussion. 


\section{REFERENCES}

1. Т а м м Т. Б., Опт. и спектр., 32, 623 (1972).

2. Reban e K., T a mm T., Abstr. of XI European Congr. Molec. Spectr., Tallinn, USSR, 1973, No. 172.

3. Т а м м Т. Б., Опт. и спектр., 32, 623 (1972).

4. Т а м м Т. Б., С а а ри П. М., Опт. и спектр., 36, 328 (1974).

5. Т а м м Т., Изв. АН ЭССР, Физ. Матем., 21, 311 (1972).

6. Ре бан е К., С а а и П., Т амм Т., Изв. АН ЭССР, Физ. Матем., 19, 251 (1970).

7. Reb a n e K., S a a ri P., T a mm T., Abstr. of V Intern. Symp. on Molec. Crystals, Philadelphia, USA, 1970 , p. 121

8. Personov R., Alshits E., B ykovskaja L., Optics Communs., 6, 169 (1972).

9. Персонов Р. И., Альшиц Е. И., Быковская Л. А., Харламов Б. М., ЖЭТФ, 65, 1825 (1973).

10. А в а р м а а Р., Изв. АН ЭССР, Физ. Матем., 23, 238 (1974).

11. Ре бане К. К., Ав арм а а Р. А., Гороховский А. А., Изв. АН СССР, Сер. физ., 39, 1793 (1975).

12. Персонов Р. И., Солодунов В. В., Опт. и спектр., 24, 142 (1968).

13. Шлол вский Э. В., УФН, 77, 321 (1962); 80, 255 (1963).

14. Ребане К., Хижняков В., Техвер И., Изв. АН ЭССР, Физ. Матем., 16, 207 (1967).

15. Hizhnyakov V., Rebane K., Tehver I., in: Light Scattering Spectra of Solids, ed. G. B. Wright, Springer-V., N. Y., 1969, p. 513.

16. Hizhnyakov V., Tehver I., Phys. Stat. Sol.. 39, 67 (1970).

17. Т а м Т. Б., Кикас Я. В., Сирк А. Э., ЖПС, 24, 315 (1976).

Academy of Sciences of the Estonian SSR, Institute of Physics

Received

Feb. 12,1976

\section{T. TAMM}

\section{MITTEHOMOGEENSUSEST TINGITUD DRASTILISED EFEKTID ŠPLOSKI SUSTEEMIDE SPEKTRITES}

On vaadeldud heade Špolski süsteemide spektrite omapärast statistilist laienemist. Temperatuuril $4,2 \mathrm{~K}$ on mōōdetud ning analüüsitud perileeni molekulide jaotuskõveraid $(0-0)$-üleminekute energiate järgi teatud tahketes maatriksites. Konstateeritakse nn. foonitsentrite olemasolu, mille jaotus on küllalt sile ning lai.

\section{T. TAMM}

\section{ЗНАЧИТЕЛЬНЫЕ ЭФФЕКТЫ НЕОДНОРОДНОСТИ В СПЕКТРАХ СИСТЕМ ШПОЛЬСКОГО}

Рассмотрено своеобразное статистическое уширение спектров хороших систем Шпольского. При $4,2 \mathrm{~K}$ измерены и обсуждены кривые распределений молекул перилена по энергиям их $(0-0)$-переходов в некоторых твердых матрицах. Отмечается существование т. н. фоновых центров с достаточно гладким и широким распределением. 